\title{
The Impact of Population Growth and Climate Change on Food Security in Africa; Looking Ahead to 2050
}

\author{
${ }^{1}$ Hall, C., ${ }^{1}$ Dawson, T.P., ${ }^{2}$ Macdiarmid, J.I., ${ }^{3}$ Matthews, R.B. and ${ }^{4}$ Smith, P. \\ ${ }^{1}$ School of the Environment, University of Dundee, Scotland, UK; ${ }^{2}$ Rowett Institute of Nutrition and \\ Health, University of Aberdeen, Scotland, UK; ${ }^{3}$ James Hutton Institute, Scotland, UK; ${ }^{4}$ Institute of \\ Biological and Environmental Sciences, University of Aberdeen, Scotland, UK
}

\begin{abstract}
Providing nutritious and environmentally sustainable food to all people at all times is one of the greatest challenges currently facing society. This problem is particularly acute in Africa where an estimated one in four people still lack adequate food to sustain an active and healthy life. In this study, we consider the potential impact of future population growth and climate change on food security in Africa, looking ahead to 2050. A modelling framework termed FEEDME (Food Estimation and Export for Diet and Malnutrition Evaluation) was used which was characterised to model the impacts of future climate changes (utilising the IPCC Special Report on Emissions Scenarios projections) and projected population growth on food availability and subsequent undernourishment prevalence in 44 African countries. Our results indicate that projected rapid population growth will be the leading cause of food insecurity and widespread undernourishment across Africa. Very little to no difference in undernourishment projections were found when we examined future scenarios with and without the effects of climate change, suggesting population growth is the dominant driver of change. Various adaptation options are discussed, such as closing the yield gap via sustainable intensification and increasing imports through trade and aid agreements. These strategies are likely to be critical in preventing catastrophic future food insecurity.
\end{abstract}

Keywords: food security; Africa; climate change; undernourishment; diet; FEEDME model; yield gap; sustainable intensification

\section{Acknowledgements}

This research contributes to the Scottish Food Security Alliance-Crops food systems theme.

\section{Disclosure statement}

No potential conflict of interest was reported by the authors.

\section{Funding}

This work was funded by a PhD studentship for $\mathrm{CH}$ from the Scottish Food Security Alliance-Crops (Universities of Aberdeen and Dundee and the James Hutton Institute), and contributes to the Belmont Forum funded DEVIL project (NERC fund UK contribution: NE/M021327/1). JIM and RBM acknowledge funding from the Rural and Environment Science and Analytical Services, Scottish Government.

\footnotetext{
*Corresponding author. Email: c.y.hall@dundee.ac.uk. Tel. 07775422346

Co-authors. 1t.p.dawson@dundee.ac.uk / 01382388064; ${ }^{2}$ j.macdiarmid@abdn.ac.uk / 01224437125 ; robin.matthews@ hutton.ac.uk / 08449285428; ${ }^{4}$ pete.smith@ @abdn.ac.uk / 01224272703
} 


\section{Introduction}

Recent estimates from the Food and Agriculture Organisation of the United Nations (FAO) suggest that one in four people in Africa lack adequate food to sustain an active and healthy life (Bremner, 2012; Food and Agriculture Organisation [FAO], 2015). While this is an improvement on 1990 levels (one in three), the total number of undernourished people has increased from 182 to 287 million, largely caused by the rapid growth in population (FAO, 2015). Whilst some African countries have successfully achieved Millennium Development Goal (MDG) targets such as 'ending extreme poverty and hunger' and 'reducing by half the proportion of people who suffer from hunger' by 2015, the overall picture for Africa is variable with progress slow overall (FAO, 2015). For example, the western sub-region has been particularly successful, reducing the number of undernourished people by $60 \%$ since 1990. Eastern and southern Africa have also made some progress, yet the middle sub-region lags behind regarding both targets (FAO, 2015). In middle Africa, the number of undernourished people has more than doubled since 1990 as a result of population growth, political instability and civil strife (FAO, 2015). It is clear that despite the improvements made over the last 25 years, undernourishment is still a serious problem in Africa and there is considerable scope for improvement. Indeed, the region continues to lag behind the rest of the world in terms of reducing chronic hunger. As is the case with achieving food security at the global scale, combating hunger and achieving food security in Africa remains a complex set of challenges, particularly in light of climate change.

Estimates suggest that Africa is the fastest growing major area in the world, with the population predicted to reach 2.4 billion in 2050 from 1.1 billion today (United Nations [UN], 2015). Consequently, more than half of the people predicted to be added to the global population between now and 2050 will be born in Africa. It should be noted that population growth in the region is projected even though families are likely to choose to have fewer children in the future. This is due to the current age structure of Africa's population, with a large number of young people still to reach their reproductive years. Even if today's young women choose to have just two children on average, the population will still dramatically increase, particularly in light of improved health care and increasing life expectancy reducing death rates. By 2100, Africa is predicted to gain about 19 years in life expectancy, reaching 70 years by 2045-2050 and 78 years by 2095-2100 (UN, 2015). However, such increases are dependent on further reductions in HIV prevalence as well as combating other infectious and non-communicable diseases (NCDs). For some of Africa's poorest countries, a five-fold increase in population is projected, including Angola, Burundi, the Democratic Republic of Congo (DRC), Malawi, Mali, Niger, Somalia, Uganda, Tanzania and Zambia, between 2015 and 2100 (UN, 2015). Such a dramatic increase in population in these countries will make eradicating poverty, inequality, hunger and malnutrition even more difficult. It is worth noting that although these population estimates assume falling birth rates, such a decline is highly uncertain due to cultural traditions, gender inequality and a lack of infrastructure, all of which sustain high birth rates across the region (Bremner, 2012). Thus, the current population estimates may be overly conservative.

As well as population growth, climate change is expected to affect food security in Africa over the coming decades. There is strong evidence to suggest that developing countries will 
be the hardest hit in terms of climate change (Brooks, Adger \& Kelly, 2005; Ikeme, 2003; Tschakert, 2007). These regions are more vulnerable to adverse climatic conditions due to high poverty rates, low adaptation capacities and poor infrastructure. Of all of the developing regions, Sub-Saharan Africa is predicted to be worst affected due to the already high temperatures, high dependency on rain-fed agriculture, and the fragility of its economy (Niasse, Afoud \& Amani, 2004). For example, irrigated farmland makes up just 5\% of all cultivated land in this region, compared to 14\% in Latin America and 37\% in Asia (Ringler, Zhu, Cai, Koo \& Wang, 2010). Climate change projections are best used on a global scale due to the high degree of variability presented when used on more local scales (Giorgi \& Mearns, 2003; Schmittner, Latif \& Schneider, 2005; Whetton, Macadam, Bathols \& O'Grady, 2007). Yet, the general circulation models (GCMs) tend to agree that average temperatures will increase across sub-Saharan Africa, albeit to differing degrees. Specifically, under a medium to high emissions scenario (Special Report on Emissions Scenarios [SRES] A1b) annual mean surface air temperature is predicted to increase between 3 and $4^{\circ} \mathrm{C}$ for the period 2080-2099 compared with the 1980-1999 period (Intergovernmental Panel on Climate Change [IPCC], 2007). In terms of precipitation, projections are more uncertain due to the high frequency spatial and temporal fluctuations but estimates have been made. For the period 2080-2099 using the SRES A1b emissions scenario it is very likely that mean annual rainfall will decrease by $20 \%$ along the Mediterranean coast, extending into northern Sahara and some of the west coast (to $15^{\circ} \mathrm{N}$ ). However, rainfall is likely to increase by approximately $7 \%$ in tropical and eastern regions (Christensen et al., 2007). Climate change will have a direct impact on food security as changes to both temperature and rainfall patterns will affect crop yields, water availability, pests and diseases, and livestock health. For example, a recent study by Knox, Hess, Deccache and Wheeler (2012) considered this impact and projected that climate change will cause a mean yield reduction of $17 \%$ in wheat, $15 \%$ in sorghum, $10 \%$ in millet and 5\% in maize across Africa by 2050.

In this study, we explore the impacts of future population and climate change scenarios on undernourishment prevalence in Africa using the Food Estimation and Export for Diet and Malnutrition Evaluation (FEEDME) model.

\section{Methods}

The FEEDME model used in this study was set up in order to model the impacts of future climate, population and socio-economic changes on food availability and subsequent undernourishment prevalence (Dawson, Perryman \& Osbourne, 2016). Undernourishment prevalence is defined here as the percentage of a population whose food intake (in terms of dietary energy in kilocalories) is insufficient to meet requirements on a continual basis. The focus on dietary energy (as opposed to nutrient intake) is justified from two standpoints;

(i) a minimum amount of dietary energy is required to maintain body weight and work performance;

(ii) if derived from normal staple foods, increasing dietary energy intake will inadvertently raise the amount of protein and other nutrients in the diet. Increasing nutrients alone is unlikely to improve nutritional status without ensuring the minimum level of dietary energy.

In other words, this measure of undernourishment focuses on hunger as opposed to undernutrition/malnutrition which has broader nutritional implications. The model uses FAO 
food balance sheets (FBSs) which compile estimates of national food production, imports, and exports to give food supply on a per-capita basis and in terms of calorific values for almost all food commodities (wild foods are not included due to a lack of data). It uses the FAO measure of food deprivation to estimate likely undernourishment prevalence at the country-level based on food supply data. Food supply is measured in terms of calorific energy per person where each country has a minimum requirement, known as a Minimum Daily Energy Requirement (MDER). The MDER is based on estimates of metabolic rate and average physical activity levels of the population in a country according to the structure of its population (age and sex). Based on the average food supply, the proportion of the population consuming less than this minimum level is considered to be undernourished.

Likewise, the model adopts the following assumptions;

(i) population structures (age and sex) remain the same as at the year 2000;

(ii) food and income inequality remain the same as in the year 2000;

(iii) MDER values in a country do not change throughout the $21^{\text {st }}$ century;

(iv) food imports to a country remain constant throughout the $21^{\text {st }}$ century;

(v) dietary patterns remain unchanged between now and 2050.

The assumption of no change to food imports (no trade) is problematic as it leads to a projected increase in undernourishment even in the absence of climate change, simply due to population growth. Therefore, in this study 'undernourishment prevalence' must be interpreted as a measure of potential undernourishment if no adaptation response is carried out. It is assumed that in response to rapid increases in hunger, national food production will be increased and/or changes will be made to international food trade agreements (such as increased imports). Similarly, the assumption that dietary patterns and foods consumed remain unchanged between now and 2050 is unlikely to be the case if there is economic development in these countries. Economic development is often accompanied with changes in dietary intake to diets high in fats, sugar, processed foods and often an increase in meat consumption, described as the nutrition transition (Popkin, Adair \& Ng, 2012). Future dietary trends are uncertain and they are not accounted for in the model, therefore this should be considered when interpreting the results of this study. For more information on the FEEDME model see Dawson et al., 2016.

In this study, 44 African countries (40 Sub-Saharan and four Middle Eastern/northern) are modelled under different climate and population scenarios. It was not possible to include all African countries in this study due to a lack of available data. We explore what would happen if the world developed according to the Intergovernmental Panel on Climate Change (IPCC) SRES emissions and socio-economic pathways (Nakicenovic \& Swart, 2000). Under SRES, four qualitative storylines yield four sets of scenarios known as 'families'; A1, A2, B1 and $\mathrm{B} 2$. A1 and $\mathrm{A} 2$ are economically focussed whereas B1 and B2 have a greater environmental focus. Likewise, A1 and B1 have a global focus and A2 and B2 are more regional. The A1 family is categorised by three groups that describe alternative directions of technological change in the energy sector. The first of these is characterised by intensive fossil fuel use (A1F1), followed by the use of non-fossil sources i.e. renewables (A1T), or a balance across all energy sources (A1b). In this study we use the Alb scenario as it is neither one extreme nor the other. The A1b scenario describes a future where global population peaks midcentury and declines thereafter, with very rapid economic growth worldwide and the 
introduction of new and efficient technologies. Major themes include the convergence of regions and a significant reduction in regional differences of per-capita income. As the A1b scenario assumes a balance across energy sources, it can be seen as a 'medium' emissions scenario.

We also examine the B1 pathway as it represents a best case scenario from an environmental perspective. B1 has the same population estimates as the A1 scenario, but is characterised by a rapid shift towards an information and service based economy, reduced material intensity and the introduction of clean, renewable energy technologies. In terms of greenhouse gas (GHG) emissions, under the $\mathrm{A} 1 \mathrm{~b}$ scenario $\mathrm{CO}_{2}$ emissions are projected to peak mid century at around $16 \mathrm{GtC} / \mathrm{Yr}$ and decline steadily thereafter until 2100. In contrast, under the $\mathrm{B} 1$ scenario $\mathrm{CO}_{2}$ peaks mid century at approximately $9 \mathrm{GtC} / \mathrm{Yr}$ and declines more rapidly towards 2100 . Similarly, under the A1b scenario a mean global temperature change of between 1.7 and $4.4^{\circ} \mathrm{C}$ is projected for the period 2090-2099 relative to $1990-1999$, with a best estimate of $2.8^{\circ} \mathrm{C}$. However, under the $\mathrm{B} 1$ scenario a change of 1.1 to $2.9^{\circ} \mathrm{C}$ is projected with a best estimate of $1.8^{\circ} \mathrm{C}$ (IPCC, 2007). $\mathrm{A} \mathrm{CO}_{2}$ fertilisation effect is accounted for within the model as described by Muller, Bondeau, Popp, Waha and Fader (2010), resulting in the following six scenarios; a mean baseline for the period 2000-2002, A1b and B1 scenarios both with and without $\mathrm{CO}_{2}$ fertilisation, and a no climate change (no $\mathrm{CC}$ ) scenario where only population growth is modelled (to examine the relative contributions of population growth and climate change).

Climate change effects are incorporated into the model using estimates taken from Muller et al. 2010 (see Table 1), who calculated the effects of temperature warming, precipitation and $\mathrm{CO}_{2}$ fertilisation on major crop yields globally at a spatial resolution of $0.5^{\circ} \times 0.5^{\circ}$. The projected changes are applied to the production quantities of all foods grown in each African country relative to the baseline production amounts. Yield simulations are based on gross primary production, biomass allocation, water-stress and growth and maintenance respiration. Percentage change in agricultural productivity is presented between two ten-year periods (1996-2005 and 2046-2055) representing an average productivity of the period 2000-2050. Agricultural productivities at national and regional scales were based on calorie- and areaweighted averages for wheat, maize, rice, millet, field pea, sugar beet, sweet potato, soybean, groundnut, rapeseed and sunflower. A generic climate change effect is assumed for these food commodities. Similarly, the FEEDME model does not account for all foodstuffs in the world, and focuses instead on the few major crops that contribute the majority of calories consumed globally (see Table 1).

\section{Results}

Undernourishment prevalence in Africa for the baseline period 2000-2002 is shown in Figure 1. The undernourishment prevalence (or undernourishment 'risk' in future scenarios) scale was adopted from the FAO Hunger Map 2015. Under all of the future scenarios, undernourishment risk significantly increases in most countries from the baseline period to 2050 (Figures 2a-d). The only countries in which undernourishment risk does not increase are South Africa, which remains at 'very low' for all scenarios, and Botswana, Lesotho, Swaziland and Zimbabwe, which all experience a reduction in undernourishment risk. This is caused by a reduction in population size in these countries partly as a result of the HIV/AIDS epidemic which the FAO factor into their future projections. 
The relative contribution of climate change is displayed in Figure 3 (no CC scenario). There is very little difference between the four scenarios with climate change and the no $\mathrm{CC}$ scenario. When comparing the mean values of all four scenarios with the no CC scenario, only two countries differ in terms of risk category. Tunisia moves from moderately low to very low risk when the climate effect is removed, while Morocco moves from very high to high risk. Thus, climate change is projected to worsen food insecurity in these two countries, but the difference is less than 5\% in both cases. These results suggest that the impact of climate change will be minor relative to the projected rapid growth in population predicted. In other words, climate change will have an impact on food security (as shown in other studies) but the increase in food demand due to population growth will overshadow its effect. Figure 4 shows the percentage of the total population at risk of undernourishment for each scenario. Again, very little difference is observed between the scenarios with and without climate change. However, the no CC scenario is less severe (lower $\%$ of population at risk) than the scenarios without $\mathrm{CO}_{2}$ fertilisation, and marginally higher than the scenarios assuming full $\mathrm{CO}_{2}$ fertilisation.

Figure 5 shows the amount of food (in tonnes) each country in Africa will require in the year 2050 in order to fulfil the dietary energy requirements (MDER values) of its population. This was calculated by estimating the 'calorie gap' in each country by taking the difference between calories required per capita and calories supplied. The calorie content (per 100g) of eight staple crops (oats, wheat, maize, millet, barley, sorghum, rye and rice) were calculated and an average taken ( $359 \mathrm{kcals}$ ) which was converted to tonnes. It is recognised that only considering these staple crops is an over-simplification of African diets, however, staple crops do provide the majority of calories in most countries, therefore it is used as a baseline. As can be seen in Figure 5 some countries such as South Africa are projected to have a surplus of food in 2050, which could be available for export.

\section{Discussion}

\subsection{Climate change effects}

There is a growing body of evidence to suggest that climate change is likely to interrupt progress towards a world without hunger (Jones \& Thornton, 2003; Parry, Rosenzweig, Iglesias, Livermore \& Fischer, 2004; Rosenzweig, Iglesias, Yang, Epstein \& Chivian, 2001; Schmidhuber \& Tubiello, 2007; Wheeler \& von Braun, 2013). Specifically, Dawson et al. (2016) estimated that climate change alone would put a further 1.7 billion people globally at risk of undernourishment by 2050 . This averages as an additional $21 \%$ of the total population of countries included in the study. Although this current study uses the same FEEDME model and general methodology as the Dawson et al. (2016) study, crop yield reduction estimates differ as we use the Muller et al. (2010) projections which are much more conservative compared to those used in the Dawson et al. (2016) paper (General Large-Area Model [GLAM] projections). The GLAM projections are around the $40 \%$ level down on the year 2000 baseline, whereas the Muller projections are all above $20 \%$ and even show a small positive yield change with full $\mathrm{CO}_{2}$ fertilisation. Similarly, we find that in this study the climate change effect is overshadowed by the increase in food demand driven by population growth.

Climate change is likely to have an impact on all food production in the future, however, in this analysis we only model changes in those cereal crops which currently provide the 
majority of dietary energy in Africa (see Table 1 in methods section). For example, the most commonly eaten cereal crops such as maize, millet, wheat and sorghum are all included. However, starchy roots such as yam, cassava and sweet potato are not included which is a limitation as they form part of many people's diets. Most of the current literature focuses on how climate change will impact the key staple crops, meaning there is a lack of data on how other foods will be affected. Similarly, a generic change is assumed for all food commodities included in the model, which is a simplification since climate change might be expected to impact foods in different ways.

It should also be noted that there is debate regarding the beneficial effects of $\mathrm{CO}_{2}$ fertilisation on crops (Long, Ainsworth, Leakey, Nosberger \& Ort, 2006; Tubiello et al., 2007) and thus, the mediating effect it has in this study is highly uncertain. This is because the mechanisms by which it improves productivity (carbon assimilation and improved wateruse efficiency) only occur if sufficient nutrients are available. If plant growth is already nutrient-limited, any additional growth will be restricted. In addition, evidence suggests that increased $\mathrm{CO}_{2}$ fertilisation can decrease the quality of crops, i.e. by reducing protein content of some grains (Taub, Miller \& Allen, 2008) and increasing susceptibility to pests (Dermody, O'Neill, Zangerl, Berenbaum, and DeLucia, 2008; Zavala, Casteel, DeLucia \& Berenbaum, 2008).

\subsection{Adaptation options for Africa}

Given the mechanistic nature of the FEEDME model, ways to address the increasing undernourishment challenge in Africa (aside from a reduction in population) such as increasing food production via sustainable intensification and/or increasing food imports via trade or aid agreements could not be included in our analysis. However, we will still discuss these adaptation options in further detail. While it is recognised that agricultural extensification (the expansion of agricultural lands into other ecosystems) is also an option for increasing production it was not considered in this study. This is because a growing body of evidence points towards extensification as the leading cause of many environmental problems, such as deforestation, habitat and biodiversity loss, and increased GHG emissions (Laurance, Sayer \& Cassman, 2014; Scharlemann, Green \& Balmford, 2004; Tachibana, Nguyen \& Otsuka, 2001; Tilman, 1999).

\subsubsection{Closing the yield gap}

Africa has fallen behind the rest of the world in terms of agricultural development and there has been no Green Revolution as there has been in other regions. This is in part due to biophysical constraints such as climate and soil quality, as well as persisting political and economic issues (Baro \& Deubel, 2006). While the global average for major cereal yield has increased substantially over the last half century (with the greatest increases in developed nations such as the UK), yields have stagnated in Sub-Saharan Africa with little to no improvements since 1960 (see Figure 6) (Brown, 2001).

In order to achieve yields close to that realised in the UK, Africa would have to increase yields of major cereal crops six-fold, which may not be possible given the less favourable bioclimatic conditions for crop growth and food production. Even if such an increase were possible, it may satisfy regional food security at present, but would not satisfy needs in the future, since production would not keep pace with the demand driven by population growth. 
Further, increasing cereal yields (such as wheat, maize, sorghum etc.) may be enough to satisfy calorific requirements, but may not be adequate for meeting nutritional needs, which require consumption of a wider range of foods. For example, meat and dairy products provide good sources of essential nutrients such as iron and vitamin $\mathrm{B}_{12}$ which are commonly deficient nutrients in developing countries, particularly in women of child-bearing age and in young children (Lartey, 2008). Likewise, fruit and vegetables provide a range of vitamins and minerals essential to health which are less common in major cereal crops. According to Lartey (2008), anaemia prevalence ranges from 21 to $80 \%$ across Africa, with similarly high values for zinc and vitamin A deficiency levels. Thus, simply increasing yields may prevent chronic energy deficiency, but will not go far enough to prevent chronic malnutrition which is currently a widespread problem. It is acknowledged a limitation of this study is that it only considered calories due to limitations of available data at the time of study, but future analysis should consider a wider range of nutrients, in particular micronutrients.

It should be noted that while closing the yield gap is a key strategy in tackling hunger, the environmental impact of increasing agricultural production must be considered. Currently, the majority of high-yielding farmlands around the world are monocultures requiring irrigation and high levels of chemical inputs, all of which negatively affect soil quality, water quality and biodiversity (Foley et al., 2005; Tilman, Cassman, Matson, Naylor, \& Polasky, 2002). It is therefore imperative that environmentally sensitive techniques are made an integral part of the intensification process and we do not carry the most destructive practices into the future, in other words making the transition from 'intensification' to 'sustainable intensification' (Garnett et al., 2013; Smith, 2013).

Nevertheless, closing the yield gap is a key element in tackling food insecurity in Africa. Major investments would be required in terms of technology, improved seed varieties, fertilisers, irrigation schemes, machinery etc. in order to boost yields and ensure the nutrient adequacy of the food supply. Arguably the most important step in this process is the regeneration of soil fertility across the continent. The case for replenishing soil in Africa was supported with evidence from large scale studies in the 1990s which revealed that yields could be increased two- to four- fold by raising soil fertility (Buresh, Smithson \& Heliums, 1997; Quinones, Borlaug \& Dowswell, 1997; Sanchez et al., 1997). Today, the overarching aim of a Green Revolution in Africa can be quantified as increasing cereal yields from one to three tons per hectare by 2020 (Sanchez, 2010). Evidence that this is possible can be seen in the 'Millennium Villages Project', set up in 2005 to assist some of the poorest communities lift themselves out of poverty, hunger and disease (Sanchez et al., 2007). Science-based interventions, alongside public-sector investments, provided these communities with improved seeds and access to fertilizers, together with basic health care, sanitation and safe drinking water. Eighty villages were part of this scheme comprising about half a million people, and as a result of the improvements, maize yields have now exceeded three tons per hectare in almost $80 \%$ of households (Sanchez et al., 2007). Consequently, dietary energy requirements are now met, or surpass the annual needs of the villagers.

\subsubsection{Increasing food imports}

Increasing food imports via trade or aid agreements to the worst affected countries may be essential to lessen the severity of food insecurity between now and 2050. Despite having agricultural potential, Africa has remained a net importer of food for over thirty years 
(Rakotoarisoa, Iafrate \& Paschali, 2001). In 2007, agricultural imports exceeded agricultural exports by around 22 billion USD. In terms of food trade, imports of meat and dairy products, edible oils and fats, sugar and cereal products to Africa have been increasing dramatically, which is associated with economic development and is often described as the nutrition transition (Popkin, 2012). Food imports have been particularly important for ensuring food security, as well as highlighting changing dietary patterns across the region in recent years (with both positive and negative health consequences). Rising food import bills can become a serious problem for the poorest countries (such as Eritrea, Central African Republic and Burundi) as money is taken away from other important developments without solving food insecurity. If agricultural productivity does not improve significantly in the near future food imports will be ever more important to ensure food security across the region. However, with food imports already very high (exceeding exports), coupled with a rapidly expanding population, increasing future import levels may be problematic (due to the high cost and socio-political issues etc.). As can be seen in Figure 5, some countries are projected to have a surplus of food in 2050 and should therefore not require any additional imports in order to meet MDERs. On the other hand, poorer countries are projected to have significant food shortages in 2050, reaching almost 37,000 tonnes in DRC. Using DRC as an example (as it is the worst affected country due to projected rapid population growth), this equates to a deficit of approximately 1080 calories per person per day. Clearly, this has major implications for the population of this country as the MDER is currently 1750 and so a loss of 1080 calories would leave just 670 calories available per person per day. It should also be noted that MDER values are based on an average persons light physical activity, thus, some people will require more than this value.

It is estimated that for the wealthier African countries with sufficient food, the combined surplus is 37,323 tonnes of food, whereas the poorer countries have a combined deficit of approximately 193,355 tonnes in the year 2050. Intra-trade (richer countries exporting excess food to poorer regions) could help to alleviate some of the problem for poorer countries. However, countries producing a surplus will have access to global markets, so may choose to export to other regions of the world rather than to their neighbours for greater economic gains. Nonetheless, poorer countries are projected to face a major food deficit in 2050 and so trade/aid agreements are likely to be critical in preventing widespread hunger.

\section{Conclusions}

This study highlights the potential severity of hunger prevalence across Africa between now and 2050 if no effective adaptation response is carried out. Our analysis suggests that rapid population growth is the driving force behind food insecurity, which in this study, overshadows the potential impact of climate change. This is not to say that the climate impact will be negligible, but instead highlights the major relative contribution of population growth. We present two key options for Africa in terms of preventing such a situation from occurring; closing the yield gap through sustainable intensification and increasing food imports through trade and aid agreements. Yield gap closure would require significant investments in technology and the regeneration of soil fertility. Increasing imports via trade and aid are likely to be critical in the future but are inhibited by social and economic issues. With regards to the recent Sustainable Development Goal to 'end hunger, achieve food security and improved nutrition and promote sustainable agriculture', Africa faces a considerable 
challenge in light of population growth, climate change and persisting political and social instability.

\section{References}

Baro, M. \& Deubel, T.F. (2006). Persistent hunger: Perspectives on vulnerability, famine, and food security in sub-Saharan Africa. Annual Review of Anthropology, 35, 521-538. doi: 10.1146/annurev.anthro.35.081705.123224

Bremner, J. (2012). Population and Food Security: Africa's Challenge. Policy Brief, Population Reference Bureau. Washington, DC: PRB.

Brooks, N., Adger, W.N. \& Kelly, P.M. (2005). The determinants of vulnerability and adaptive capacity at the national level and the implications for adaptation. Global Environmental Change, 15, 151-163. doi:10.1016/j.gloenvcha.2004.12.006

Brown, L. (2001). Eradicating hunger: a growing challenge. In L. Starke (Ed.), State of the world 2001: A Worldwatch Institute report on progress toward a sustainable society (pp. 4362). New York: Norton.

Buresh, R.J., Smithson, P.C. \& Heliums, D.T. (1997). Building soil phosphorus capital in Africa. In R.J. Buresh, P.A. Sanchez \& F.G. Calhoun (Eds.), Replenishing soil fertility in Africa. SSSA Special Publication Number 51 (pp. 111-149). Madison, USA: Soil Science Society of America. doi: 10.2136/sssaspecpub51.c6

Christensen, J.H., Hewitson, B., Busuioc, A., Chen, A., Gao, X., Held, I., ... Whetton, P. (2007). Regional Climate Projections. In S. Solomon, D. Qin, M. Manning, Z. Chen, M. Marquis, K.B. Averyt, M. Tignor \& H.L. Miller (Eds.), Climate Change 2007: The Physical Science Basis. Contribution of Working Group I to the Fourth Assessment Report of the Intergovernmental Panel on Climate Change. Cambridge, UK: Cambridge University Press.

Dawson, T.P., Perryman, A.H. \& Osborne, T.M. (2016). Modelling impacts of climate change on global food security. Climatic Change, 134, 429-440. doi:10.1007/s10584-014$1277-\mathrm{y}$

Dermody, O., O'Neill, B.F., Zangerl, A.R., Berenbaum, M.R. \& DeLucia, E.H. (2008). Effects of elevated $\mathrm{CO}_{2}$ and $\mathrm{O}_{3}$ on leaf damage and insect abundance in a soybean agroecosystem. Arthropod-Plant Interactions, 2, 125-135. doi:10.1007/s11829-008-9045-4

Foley, J.A., DeFries, R., Asner, G.P., Barford, C., Bonan, G., Carpenter, S.R., ... Helkowski, J.H. (2005). Global consequences of land use. Science, 309, 570-574. doi:10.1126/science.1111772

Food and Agriculture Organisation of the United Nations [FAO] (2015). The State of Food Insecurity in the World 2015. Meeting the 2015 international hunger targets: taking stock of uneven progress. Rome: Food and Agriculture Organisation of the United Nations.

Garnett, T., Appleby, M.C., Balmford, A., Bateman, I.J., Benton, T.G., Bloomer, P., ... Herrero, M. (2013). Sustainable intensification in agriculture: premises and policies. Science, 341, 33-34. doi:10.1126/science. 1234485

Giorgi, F., \& Mearns, L.O. (2003). Probability of regional climate change based on the Reliability Ensemble Averaging (REA) method. Geophysical Research Letters, 30, 1629. doi: 10.1029/2003GL017130 
Ikeme, J. (2003). Climate change adaptation deficiencies in developing countries: The case of sub-Saharan Africa. Mitigation and Adaptation Strategies for Global Change, 8(1), 29-52. doi:10.1023/A:1025838610473

Intergovernmental Panel on Climate Change [IPCC] (2007): Climate Change 2007: Impacts, Adaptation and Vulnerability. Contribution of Working Group II to the Fourth Assessment Report of the Intergovernmental Panel on Climate Change. Cambridge, UK: Cambridge University Press.

Jones, P.G. \& Thornton, P.K. (2003). The potential impacts of climate change on maize production in Africa and Latin America in 2055. Global Environmental Change, 13(1), 5159. doi:10.1016/S0959-3780(02)00090-0

Knox, J., Hess, T., Daccache, A. \& Wheeler, T. (2012). Climate change impacts on crop productivity in Africa and South Asia. Environmental Research Letters, 7, 034032. doi:10.1088/1748-9326/7/3/034032

Lartey, A. (2008). Maternal and child nutrition in sub-Saharan Africa: challenges and interventions. Proceedings of the Nutrition Society, 67(1), 105-108. doi:10.1017/S0029665108006083

Laurance, W.F., Sayer, J., \& Cassman, K.G. (2014). Agricultural expansion and its impacts on tropical nature. Trends in ecology \& evolution, 29, 107-116.

doi:10.1016/j.tree.2013.12.001

Long, S.P., Ainsworth, E.A., Leakey, A.D.B., Nosberger, J. \& Ort, D.R. (2006). Food for thought: Lower-than-expected crop yield stimulation with rising $\mathrm{CO}_{2}$ concentrations. Science, 312, 1918-1921. doi:10.1126/science.1114722

Muller, C., Bondeau, A., Popp, A., Waha, K. \& Fader, M. (2010). Climate change impacts on agricultural yields. Background note to the World Development Report 2010: Development and Climate Change. Washington DC, USA: Potsdam Institute for Climate Impact Research, World Bank.

Nakicenovic, N. \& Swart, R. (2000). Special Report on Emissions Scenarios: A special report of working group III of the Intergovernmental Panel on Climate Change. Cambridge, UK: Cambridge University Press.

Niasse, M., Afoud, A., \& Amani, A. (2004). Reducing West Africa's vulnerability to climate impacts on water resources, wetlands and desertification: Elements of regional preparedness and adaptation. Gland, Switzerland and Cambridge, UK: International Union for Conservation of Nature.

Parry, M.L., Rosenzweig, C., Iglesias, A., Livermore, M. \& Fischer, G. (2004). Effects of climate change on global food production under SRES emissions and socio-economic scenarios. Global Environmental Change, 14(1), 53-67. doi:10.1016/j.gloenvcha.2003.10.00

Popkin, B.M., Adair, L.S. \& Ng, S.W. (2012). Global nutrition transition and the pandemic of obesity in developing countries. Nutrition Reviews, 70(1), 3-21. doi:10.1111/j.17534887.2011.00456.x

Quinones, M.A., Borlaug, N.E. \& Dowswell, C.R. (1997). A fertilizer based green revolution for Africa. In R.J. Buresh, P.A. Sanchez \& F. Calhoun (Eds.), Replenishing Soil Fertility in Africa. SSSA Special Publication Number 51 (pp. 81-95). Madison, USA: Soil Science Society of America. doi:10.2136/sssaspecpub51.c4 
Rakotoarisoa, M.A., Iafrate, M. \& Paschali, M. (2012). Why has Africa become a net food importer? Explaining Africa agricultural and food trade deficits. Rome, Italy: Food and Agriculture Organization of the United Nations.

Ringler, C., Zhu, T., Cai, X., Koo, J. \& Wang, D. (2010). Climate change impacts on food security in sub-Saharan Africa. (Discussion Paper No. 01042). Washington DC, USA: International Food Policy Research.

Rosenzweig, C., Iglesias, A., Yang, X., Epstein, P. \& Chivian, E. (2001). Climate change and extreme weather events: Implications for food production, plant diseases, and pests. Global Change and Human Health, 2, 90-104. doi:10.1023/A:1015086831467

Sanchez, P.A. (2010). Tripling crop yields in tropical Africa. Nature Geoscience, 3, 299-300. doi:10.1038/ngeo853

Sanchez, P.A., Palm, C., Sachs, J., Denning, G., Flor, R., Harawa, R., ... Zamba, C. (2007). The African millennium villages. Proceedings of the National Academy of Sciences, 104, 16775-16780. doi:10.1073/pnas.0700423104

Sanchez, P.A., Shepherd, K.D., Soule, M.J., Place, F.M., Buresh, R.J., Izac, A.M.N., ... Woomer, P.L. (1997). Soil fertility replenishment in Africa: An investment in natural resource capital. In R.J. Buresh, P.A. Sanchez \& F. Calhoun (Eds.), Replenishing Soil Fertility in Africa. SSSA Special Publication Number 51 (pp. 1-46). Madison, USA: Soil Science Society of America. doi:10.2136/sssaspecpub51.c1

Scharlemann, J.P., Green, R.E., \& Balmford, A. (2004). Land-use trends in Endemic Bird Areas: global expansion of agriculture in areas of high conservation value. Global Change Biology, 10, 2046-2051. doi:10.1111/j.1365-2486.2004.00860

Schmidhuber, J. \& Tubiello, F.N. (2007). Global food security under climate change. Proceedings of the National Academy of Sciences, 104, 19703-19708. doi:10.1073/pnas.0701976104

Schmittner, A., Latif, M. \& Schneider, B. (2005). Model projections of the North Atlantic thermohaline circulation for the 21 st century, assessed by observations. Geophysical Research Letters, 32, L23710. doi:10.1029/2005GL024368.

Smith, P. (2013). Delivering food security without increasing pressure on land. Global Food Security, 2(1), 18-23. doi:10.1016/j.gfs.2012.11.008

Tachibana, T., Nguyen, T.M., \& Otsuka, K. (2001). Agricultural intensification versus extensification: a case study of deforestation in the northern-hill region of Vietnam. Journal of Environmental Economics and Management, 41(1), 44-69. doi:10.1006/jeem.1998.1131

Taub, D.R., Miller, B. \& Allen, H. (2008). Effects of elevated $\mathrm{CO}_{2}$ on the protein concentration of food crops: a meta-analysis. Global Change Biology, 14, 565-575. doi:10.1111/j.1365-2486.2007.01511

Tilman, D. (1999). Global environmental impacts of agricultural expansion: the need for sustainable and efficient practices. Proceedings of the National Academy of Sciences, 96, 5995-6000. doi:10.1073/pnas.96.11.5995

Tilman, D., Cassman, K.G., Matson, P.A., Naylor, R. \& Polasky, S. (2002). Agricultural sustainability and intensive production practices. Nature, 418, 671-677.

doi:10.1038/nature01014 
Tschakert, P. (2007). Views from the vulnerable: Understanding climatic and other stressors in the Sahel. Global Environmental Change, 17, 381-396.

doi:10.1016/j.gloenvcha.2006.11.008

Tubiello, F.N., Amthor, J.S., Boote, K.J., Donatelli, M., Easterling, W., Fischer, G., ... Rosenzweig, C. (2007). Crop response to elevated $\mathrm{CO}_{2}$ and world food supply - A comment on "Food for Thought..." by Long et al., Science 312: 1918-1921, 2006. European Journal of Agronomy, 26, 215-223. doi:10.1016/j.eja.2006.10.002

United Nations (2015). World Population Prospects: The 2015 Revision, Key Findings and Advance Tables (Working Paper No. ESA/P/WP.241). New York, USA: The Department of Economic and Social Affairs of the United Nations.

Wheeler, T. \& von Braun, J. (2013). Climate change impacts on global food security. Science, 341, 508-513. doi:10.1126/science.1239402

Whetton, P., Macadam, I., Bathols, J. \& O'Grady, J. (2007). Assessment of the use of current climate patterns to evaluate regional enhanced greenhouse response patterns of climate models. Geophysical Research Letters, 34, L14701. doi:10.1029/2007GL030025

World Bank (2016) Cereal yield data. Available at:

http://data.worldbank.org/indicator/AG.YLD.CREL.KG. Accessed: $29^{\text {th }}$ March 2016.

Zavala, J.A., Casteel, C.L., DeLucia, E.H. \& Berenbaum, M.R. (2008). Anthropogenic increase in carbon dioxide compromises plant defense against invasive insects. Proceedings of the National Academy of Sciences, 105, 5129-5133. doi:10.1073/pnas.0800568105 


\section{List of tables}

Table 1 - Impacts of $\mathrm{CO}_{2}$ fertilization and regional mean climate change on sub-Saharan Africa and Middle Eastern/North Africa (\% change in 2046-2055 relative to 1996-2005) on current (2000) cropland. Data extracted from Muller et al. 2010

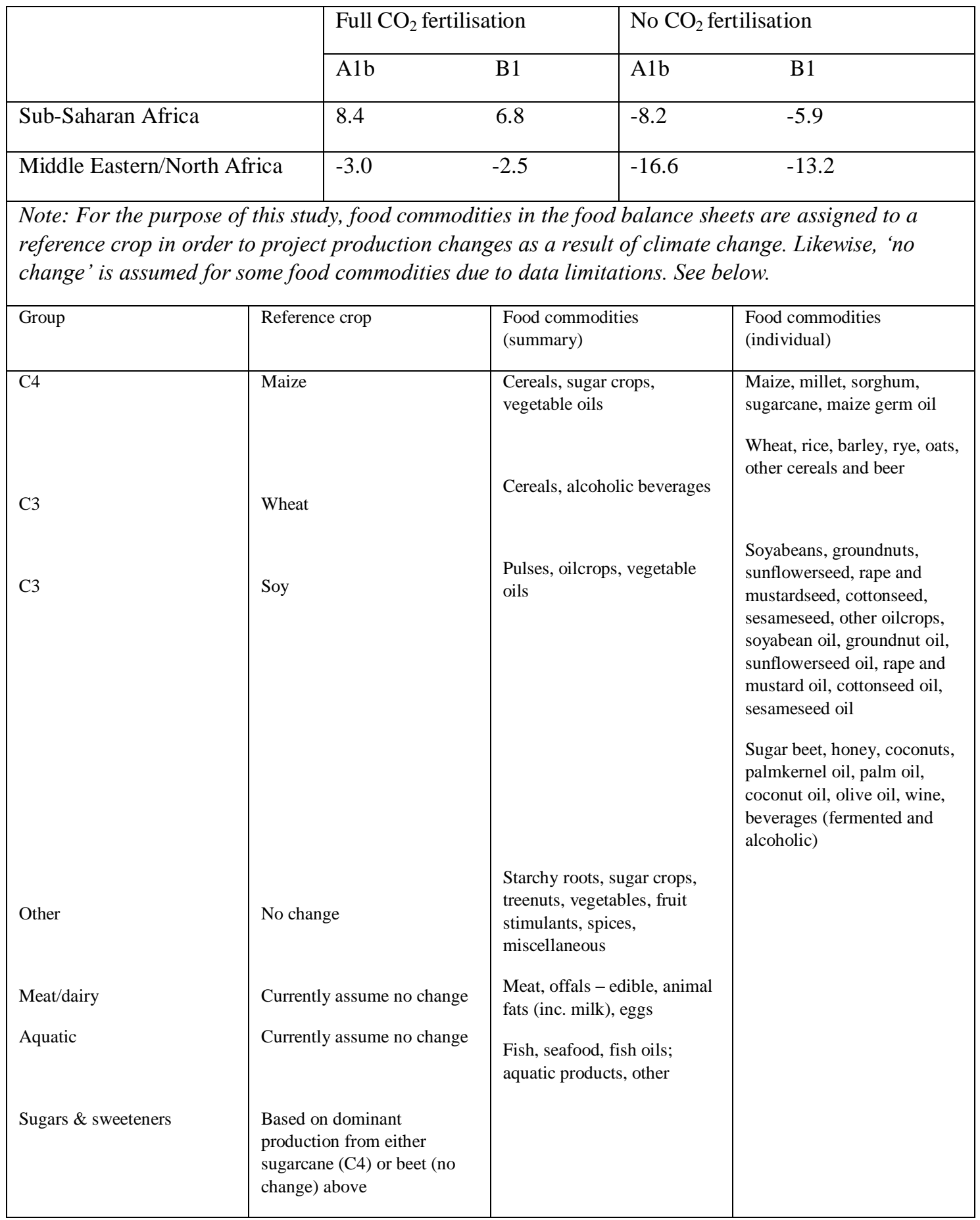




\section{List of figure captions}

Figure 1 - Map of Africa showing the proportion of the population undernourished in each country for the baseline period 2000-2002 as simulated by the FEEDME model.

Figure 2 - Panel of maps showing future undernourishment risk for the year 2050 under the following scenarios (a) A1b with full $\mathrm{CO}_{2}$ fertilisation, (b) $\mathrm{B} 1$ with full $\mathrm{CO}_{2}$ fertilisation, (c) A1b with no $\mathrm{CO}_{2}$ fertilisation, and (d) $\mathrm{B} 1$ with no $\mathrm{CO}_{2}$ fertilisation.

Figure 3 - Map showing future undernourishment risk in Africa in 2050, accounting for population growth but without the effects of climate change (Scenario - no CC).

Figure 4 - Graph showing the percentage of the whole population at risk of undernourishment for each scenario $\left(\mathrm{FCO}_{2}=\right.$ full $\mathrm{CO}_{2}$ fertilisation, $\mathrm{NCO}_{2}=$ no $\mathrm{CO}_{2}$ fertilisation). Note; 'whole population' refers to the sum of all 44 countries examined in this study.

Figure 5 - Graph showing additional food (in tonnes) required in each country in order to fulfil the calorific requirements of the population for the year 2050. Values are a mean of all four future climate/population scenarios and countries are ranked from lowest (need the least - some countries have a surplus of calories) to highest (require the greatest - countries with a deficit).

Figure 6 - Graph showing the difference in cereal yields between the global average, SS Africa (sub-Saharan Africa), and the UK from 1960 to 2013. Yield is measured as kilograms per hectare of harvested land including wheat, maize, rice, barley, oats, millet, rye, buckwheat, sorghum and mixed grains. Data relates to cereals harvested for dry grains only, i.e. crops harvested for hay, silage, animal feeds and those used for grazing are not included. [Data extracted from The World Bank online database (http://data.worldbank.org/indicator/AG.YLD.CREL.KG)]

\section{List of figures}

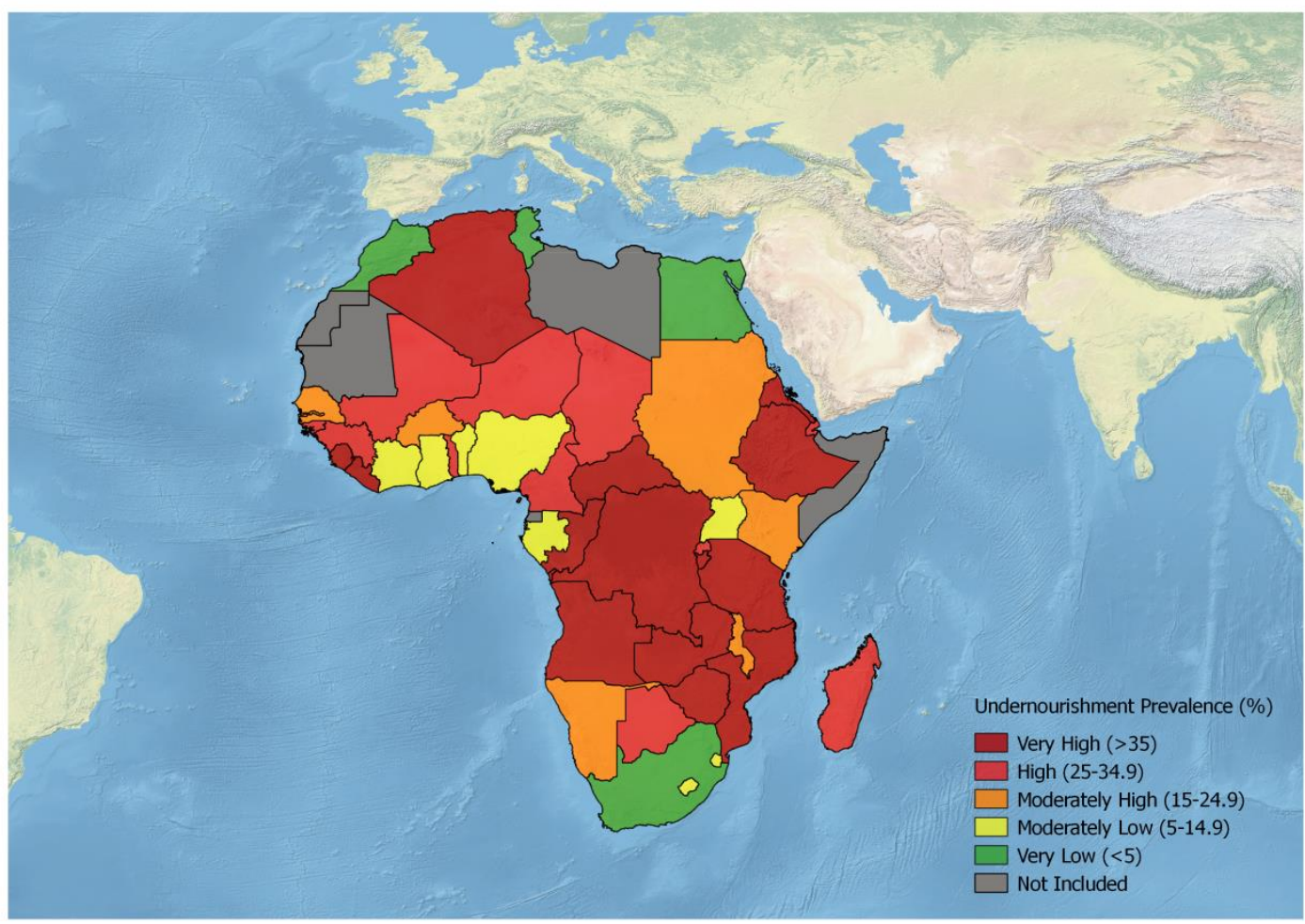


Figure 1
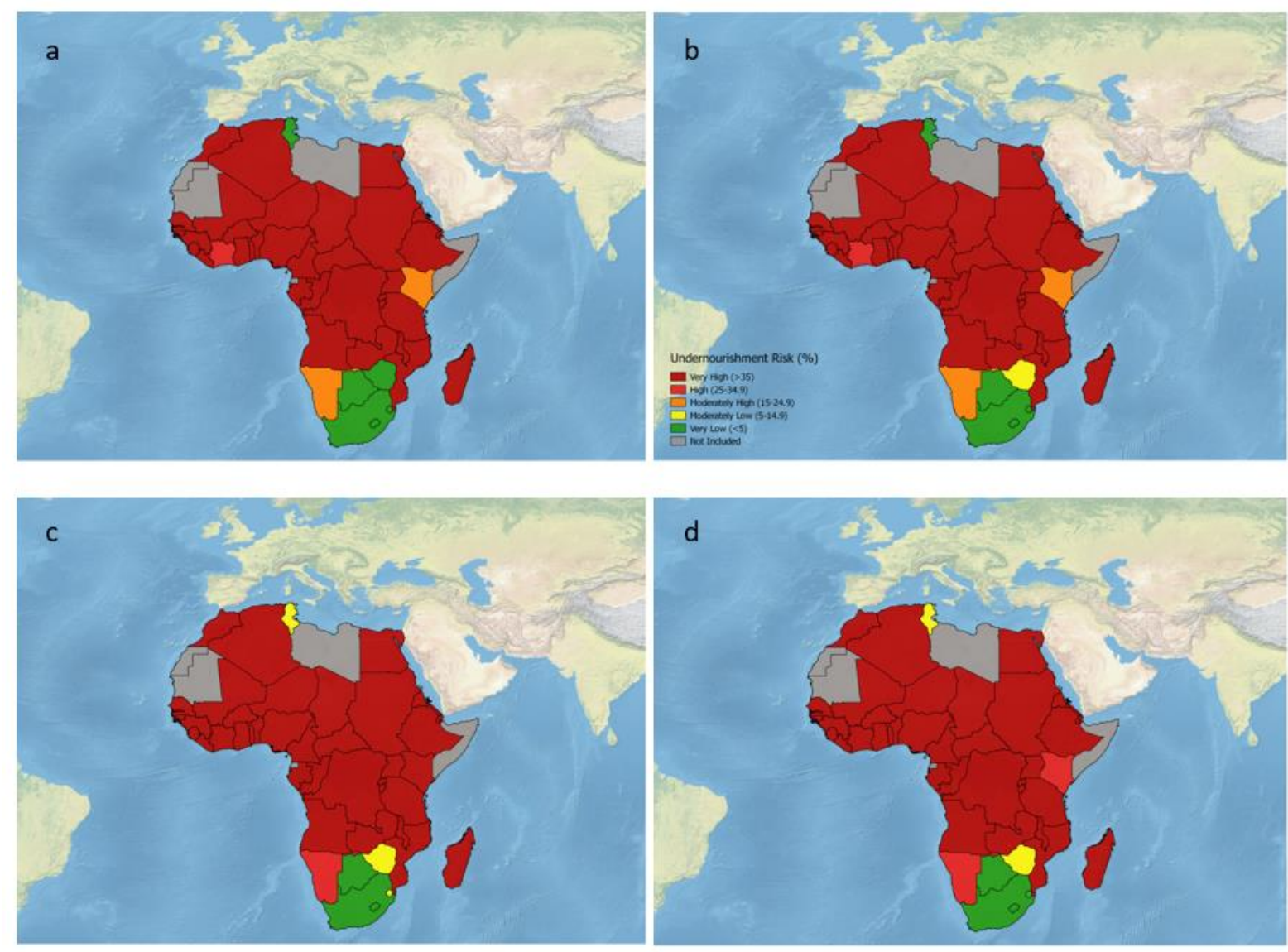

Figure 2 (a-d) 


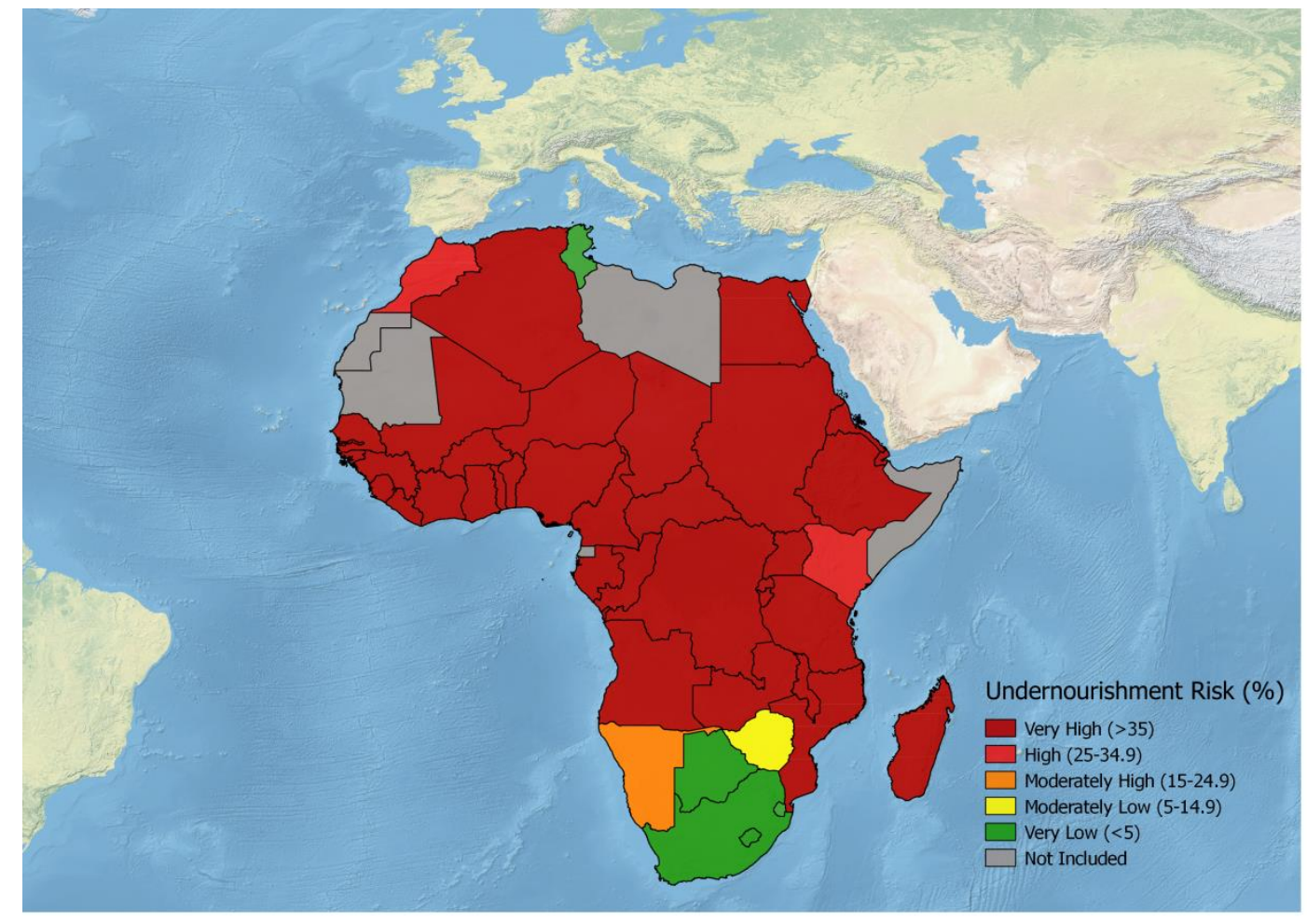

Figure 3

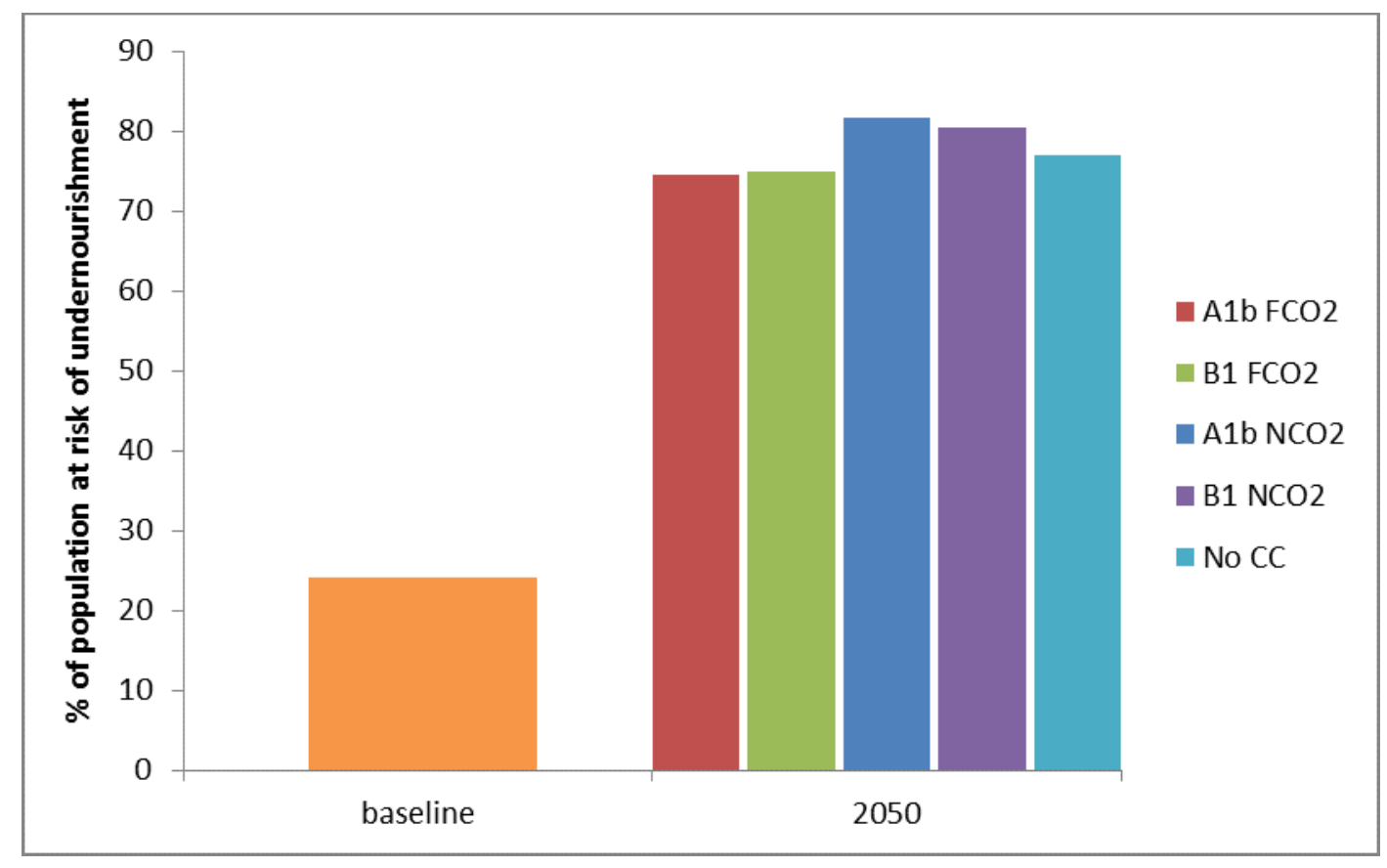

Figure 4 


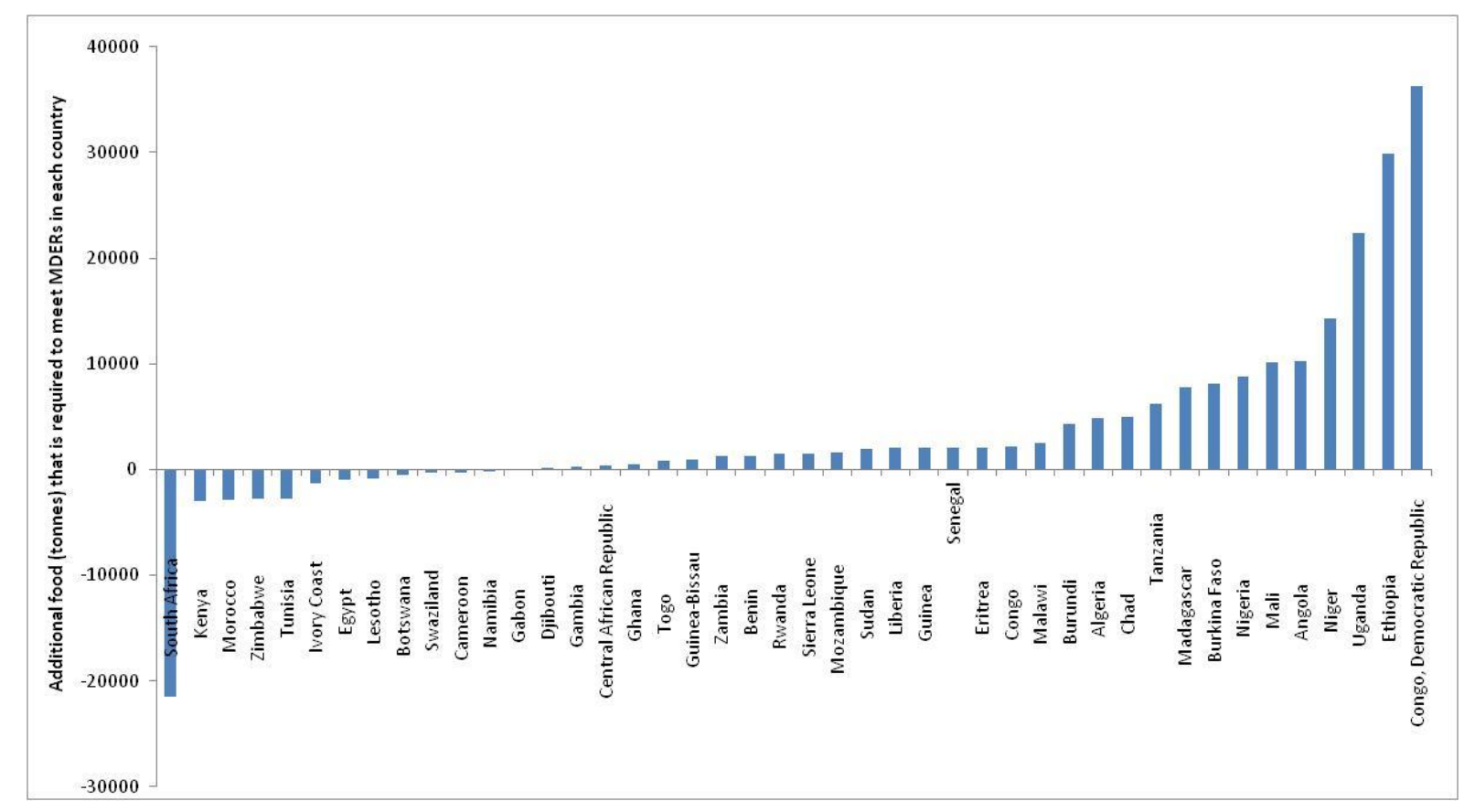

Figure 5

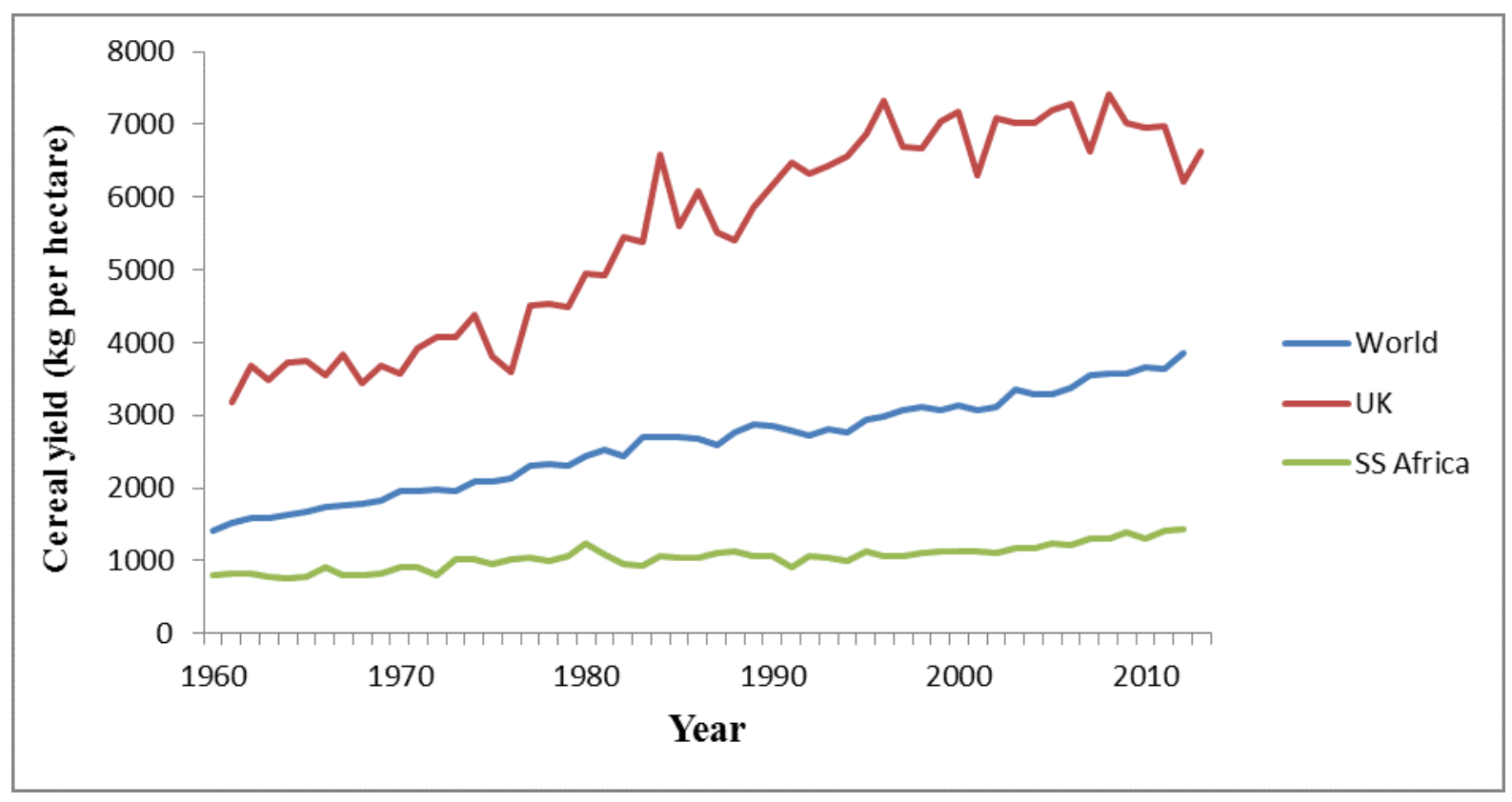

Figure 6 
